\title{
CHAPTER TWENTY-FOUR
}

\section{THE RIGHT TO CHOICE*}

\author{
Ottoman, ecclesiastical and communal justice \\ in Ottoman Greece
}

\author{
Eugenia Kermeli
}

$\mathrm{T}$

The Ottoman empire as a multilingual, multicul cural and multi-erhnic state attracted

the attention of European writers, particularly travellers, from the sixteenth century onw:rds. The personal interests of such writers necessarily varied - from initial analyses of impressive Ottoman institutions such as the janissaries, in order to explain Ottoman success on the batrlefield, to discussion towards the end of the empire of the reasons for its downfall. Non-Muslim Ottoman subjects also received a fair amount of attention, the common theme being ways of survival under the unpredictable Otcoman yoke. In contrast, modern historicil research which addresses the issue of coexistence of Muslims and non-Muslims in the empire has found this to be mostly peaceful and generally devoid of the social tensions experienced in Europe in the early modern period.

According to Braude and Lewis, the Ottoman empire, as a classical example of a plural society, allowed a great degree of communal autonomy.' The famous millet system, ${ }^{-}$initiated shortly after the conquest of Constantinople in 1453, classified the empire's zimmis (non-Muslims) into Jewish, Armenian and Orthodox millets, each presided over by its own religious authorities approinted by Istanbul to oversee the empire-wide affairs of the community. This millet system as a socio-cultural and communal framework based on religion and ethnicity used to be considered the basis for the nationalism that tore the empire apart in the nineteenth and early twentiech centuries. ${ }^{3}$ Notwithstanding traces of 'proto-nationalism' among some non-Mustims from the late eighteenth century onwards, there is now a consensus that such a well-organized millet system was a latter-day Ottoman institution 'that had been retrospectively ciast inter the past in the form of "foundation mychs"'.

However, while the existence of an early, official and empire-wide 'system' has been rightly questioned, the issue of essential legal autonomy for non-Muslim communities remains. Although appointment letters show that the Porte allowed the Orthodox patriarchs to adjudicatte in cases of Christian family law, marriage, divorce and inheritance, there has been heated historical debatte over the extent of juriscliction of ecclesiasticil courts and their power to impose their decisions. The presence of many non-Mustims in the courts of the Ottoman kadi (judge) even for family law cases has led historians to question the very existence of separate legal forums for Chris- 
tians. Records show that, for whatever reasons, and despite the fact that zimmi sources often describe them as corrupt and discriminatory, non-Muslims frequently resorted ro Otroman kadi courts. Ronald C. Jennings notes that non-Muslim courts are never mentioned in the sicil records of the kadi courts, a fact which could lead historians to 'suppose that [the zimmis] had no internal judicial apparatus of their own or at least a very weak one'.' This apparent failure of parochial leadership to exert its legal prerogatives has been viewed as a function of Ottoman councerregulations, of Ottoman equivocation, or of weak communal organization."

From a different point of view, the legal choice enjoyed by Otcoman subjects in their pursuit of justice has been discussed primarily as a privilege granted to the non-Muslim populations of the empire. ${ }^{7}$ Scholars such as Aryeh Shmuelevitz, Joseph Hacker and Nicolaos Pancazopoulos have used responsa and patriarchal and synodical lecters to prove the existence of separate courts operating in the Ottoman empire for Christians and Jews. They have illuminaced the points of cension between these separate courts and the kadi courts of Islamic law - censions which emanated from the doctrinal differences and procedural pracrices of differenc bodies of law. ${ }^{8}$ They have also focused on the level of legal auconomy enjoyed by non-Muslim subjects and on questions posed by scholars' utilization of kadi court records. If indeed the zimmis (Chriscians and Jews) had the right co sectle most of their legal affaits in officially and communally recognized zimmi courts - when these cases did nor cross religious boundaries, involve capital crimes, or threacen public order and security - how can we explain their ope ing for kadi courts, especially in family law cases? In her scudy of the kadi court of Sofia, Rossitsa Gradeva argues that Chriscians preferred the Ottoman court because it provided betrer documentation, lower fees, more favourable procedures and a greater likelihood of being able to enforce its rulings. " Litigants had access to cerrain rights if they applied outside their own legal system. For example, Jewish women could get a divorce and claim inheritance. "' However, these are examples of legal awareness and a legal environment readily offering advice to individuals regardless of their religious or legal status. They do not address the question of the legal auconomy of zimmis or the degree of this autonomy.

\section{ECCLESIASTICAL AND COMMUNAL JUSTICE: SOURCES AND SCOPE}

Historical evidence for the study of zimmi courcs is problematic. For Jewish communities, the communal court records required to balance the information gained from Ottoman sicils (kadi court records) have been lost: 'for all intents and purposes there exists today not a single series of Jewish court records'. "Responsa collections are restricted to a specific community or time period. ${ }^{12}$ However, for the Orthodox Church in the Greek lands of the empire, ecclesiastical and communal court records are preserved in considerable numbers in the national and local archives of Greek cities and monasteries. These have been litcle used. ${ }^{13}$ There are many reasons for the silence surrounding these sources in historical discourse. The major hurdle is an ideological one. Even roday, some Greek scholars argue vigorously about the privileges given to the patriarch, and his instrumental role and that of the Church in preserving Greek mational identity through the millet system during 'the long and dark ages of the 
'Turkish yoke' (tourkokratia). For these scholars, pacriarchal letrers and synodical and canonical orders prove the existence of a centralized system. They also demonstrate the degree of obedience required by the patriarch and offered by his obedient local dignitaries and lay Christians. Thus, the three canonical orders sent by the Patriarch Maximos II some time between 1476 and I 482 to instruct judges and to scress that marriage cases should be judged only by bishops are evidence that a judicial system existed in the fifteenth century. ${ }^{14}$ However, the challenge is not to prove the existence of such judicial bodies, but to determine their jurisdiction, to discuss the body of law used, and to explore the degree of inreraction between different legal systems in the Otcoman empire.

The appointment documents (berats) of patriarchs and metropolitans allow us to analyse the degree of judicial jurisdiction given by the Otromans to the Orthodox Church and how this changed over rime. Elizabeth Zachariadou, in a study of the earliest Otroman documents relating to the Orthodox Patriarchate, has questioned the nocion of privileges being given to the first patriarch, Gennadios Scholarios, by Mehmed II. ${ }^{15}$ She depicts an institurion subordinated to and in need of Ottoman executive auchority. ${ }^{\text {t" }}$ The majority of ecclesiastical court records date from the seventeenth century, which raises the question of why local bishops began to document their decisions at that point. Was it as a result of a change in their judicial auchority or in line with general developments in Ottoman sociecy? Did episcopal decisions carty more weight in litigarion processes if used in orher courts from the seventeenth century onwards? Did Christians begin to apply more frequently to communal courts, or were they simply more conscious of their rights and betrer informed on legal procedures? Other issues to explore would be rhe extenc of adherence to the ecclesiasrical judicial jurisdiction granted by the Otromans, and whether local societies and bishops oversaw other civil matters in addicion to family affairs and arbitration cases. An investigation of the inceraction berween kadi and ecclesiastical courts, and wherher the local bishop accepred the kadi's decisions, would allow us to determine the degree of autonomy enjoyed by zimmi courts.

On this last point, we should consider wherher zimmi courts were simply arbitracion bodies or whether they were established courts whose decisions were respecred and imposed. The problem modern scholars face in answering this quescion stems from Austinian legal posicivism and the ninereenth-century bourgeois liberal understanding that the word 'law' was restricted to social control exercised by the state, and that the scate retained the exclusive right to exercise coercion. In such a case, we could expect to see a linear structure of non-Muslim courts $\rightarrow$ kadi courr (local Muslim judge) $\rightarrow$ divan court (imperial appeal courc). In fact, it is clear that, by excommunication or imposition of fines on local communities, a non-Muslim courc actually possessed a considerable degree of coercion. Research also shows that, despite the fact that non-Muslim coures had to accepe the decisions of other courts, implementing such decisions was not always possible. Further, litigants did not always follow a linear order, but applied to different forums according to their legal strategy, using the decisions of one forum as a legal tool in another. Thus, non-Muslim legal forums were more chan arbicration bodies, and will be considered here as courts even if some of them, especially the communal ones and ecclesiastical courts adjudicating on civil cases, lacked official recognition.

In ecclesiastical courrs, canonical and Byzantine law formed the corpus of law utilized by the bishop. In communal courrs, we obseive regional variations termed 'local 
custom' (in Orroman, adet). Most surviving community records are located in the Aegean islands, where for historical and geographical reasons, such as an island's status before conquest and the way an area was incorporated inco the Ottoman system, the legal system developed in an idiosyncratic manner. 'Local custom' was a mixcure of Byzancine, canonical, Latin/Venerian and Otcoman influences. Unlike ecclesiastical records, which concentrate primarily on family maters, community records are a rich source of cases relaced to taxation, intercommunal administration, civil matcers, family law and even (albeic rarely) criminal law. Here again, researchers have differene ideological perspectives. For some, these records are the best examples of a communal organization centred on the Church, funcrioning as 'pockers of resistance' and as 'fine examples of independene socieral bodies raking the lead in the struggle against the oppressors in the ninereenth cencury'. ${ }^{17}$ For orhers, these are examples of idiosynciaric insularités, a result of the inceraction becween geography and the nature of the Orcoman presence in the region. ${ }^{18}$

The sources available on ecclesiastical justice before the first ecclesiastical courc records of the seventeenth century are mainly leeters sent to the patriarch from local bishops, or orders from him ro local bishops to atcend to the affairs of laymen who had requested his arbitration. One of the earliest extant references, concerning a litigation process conducred by ecclesiastical auchoricies, indicates Greek arcirudes to Ortoman rule on the Aegean island of Limnos within ewency years of its conquest." Around I 500 , the metropolitin of Limnos wrote to the monastic council at Karyes in Mount Athos concerning litigation over a sheep-run benseen the dependencies of the Achonite monasteries of Dionysiou and of Pancokrator on the island. The case had been judged by the metropolitan himself with the help of the elders, who are the signatory witnesses in the document. In terms of procedure, the litigants (the representarives of the rwo monastic dependencies), Kallistos of rhe Dionysiou monastery and Neophytos of Pancokrator, were present. The elders were summoned and 'under threat, on pain of spiritual punishment', were asked 'for the truth'. On close examination of the charters of borh parries, they concluded unanimously in favour of the Dionysiou monastery. Although this must have been the end of the dispute, the metropolitan's lecter states that Neophytos of the Pancokrator monastery had been 'unruly' and had threatened to rake his case co foreigners - i.e., the Orcoman auchorities. It was for this reason that the letcer was sent to the monlss of Mount Athos, his superiors. The metropolitan urged that there should be no disorder or 'spreading of scandal among the barbarians [rhe Orxomans]'. The defianc Neophyros was threarened with aphorism (excommunication), the only tool available in the hands of the Church. The witnesses ro the case are of interest. Nine Chriscians and three Muslims - possibly converts - signed the document. Of the nine, five were clearly religious men (priests or monks), one was the son of a priest, and the orhers had the title 'kyr' (lord), denoting their high position in sociery. The presence of new Muslims as wirnesses does nor signify a shared court, but suggests that they remained respected social elders. This letcer indicates that, already by 1500 , while the justice of the metropolitan was binding on the local community, litigants reserved the right - and somerimes exercised it - to plead their cases to the Otcoman auchorities. It was through fear of incerference that the ecclesiastical and communal authorities tried to prevent this. ${ }^{20}$

Patriarchal and merropolitan lecters and orders concentrated primarily on family law and the internal organization of the Church. Occasionally, ecclesiastical 
authorities were asked to intervene in dispures by adopting an arbitration role rather than a formal judicial one. ${ }^{21}$ The tool used to persuade wrongdoers was the threat of excommunication, a powerf ul weapon in pre-modern socieries. ${ }^{22}$ Only rhe Ottomans had actual executive power, as indicated in the berats of appointment of patriarchs and metropolitans, wherein the Otcoman administration explicitly def ined the boundaries of ecclesiastical judicial jurisdiction.

It is apparent that any privileges given were personal to the patriarch and not to the Church, ${ }^{2 \cdot 3}$ and that ecclesiastical jurisdiction was restricted to family law only. Here, the sultan recognized adet (custom) and did not refer to the karnsn (administrative law). In a berat issued by Bayezid II in 1483, Patriarch Symeon was granted aurhority to appoint and remove his clergy at will and to inherit from them. The patriarch was to oversee marriage, divorce and inheritance according to their 'custom'. If a lay Christian did not marry or divorce according to religious practices, then he or she could not be accepted in the Church. ${ }^{24}$ On inheritance, a berat of Sïleyman issued in $x 525$ to Patriarch leremias permitted the involvement of the Otcoman provincial authorities if the heirs in a disputed case referred the matter to them. ${ }^{25}$ This is the first known mention of the right to judicial choice for the Christians of the empire in inheritance cases.

Seventeentbcentury berats further elaborate the patriarch's right to punish. In 1688, the metropolitan of Crete, Athanasios, was granted a derailed appointment order clarifying his financial responsibilities to the Porte, his right to inherit from clergymen and to collect ecclesiastical dues. Additionally, he was allowed to punish priests who refused to pay their taxes to the treasury. ${ }^{26}$ This development was related to the change in the tax collection system in the seventeenth century. As local communities were collectively responsible for the payment of their taxes, local bishops functioned as tax collectors in the iltizam (tax farming) system. ${ }^{27} \mathrm{~A}$ bishop's right to punish those who defied religious laws on marriage was also upheld: the sultan forbade local Ottoman officials such as kadis, naibs (depucy kadis) and dignitaries from imposing fines, a ruling which indicates that there had been encroachment on previously accepted judicial rights of the Orthodox Church. ${ }^{28}$ The sultan also forbade similar attempts when the bishop imposed an oath or aphorism in marital disputes.

A further development regarding the judicial authority of bishops was established in the 1704 berat of the metropolitan of Crece, in which he was permitred to act as arbitrator between lay Christians who had jointly agreed ro submit to his judgement, and ro administer oaths as part of Church procedure." The long-established practice of arbitration seen in patriarchal and episcopal orders is here reflected in an Otroman order.

Clearly, the authority of the Church to adjudicate marriage, divorce and inheritance issues of lay Christians, though established as a personal privilege granted by the sultan to patriarchs and metropolitans from the fifieenth century onwards, did nor deter the interf erence of local Ottoman dignitaries. The numerous warnings against their encroachment included in the berats reflected a continual struggle between the Church and the Ottoman central administration. On the one hand, the administration recognized the Church with limited judicial rights; on the other, it was not willing to limit the individual judicial freedom of its subjects to submit to the legal body of their choice. However, the extension of judicial jurisdiction to include cases of amicable settlement should not be viewed as an establishment of the authority of the Church 
over its people. When this occurred, it was an external rather than an internal development. The changes in seventeenth-century Ottoman society and the expansion of the tax-farming system, with religious leaders participating as tax farmers, resulted in the strengthening of local communities, as they were collectively responsible for their obligations to the administration. This then gave the Church and other local elements the opportunity to establish authority over the zirmmis, in their role as agents/mediators between the centre and the periphery. ${ }^{* \prime \prime}$

\section{ECCLESIASTICAL COURTS AND CODICES}

In ecclesiastical courts, litigants made an oral request to apply to the court and were summoned to appear together, unless onc of them presented a wristen sratement instead. Cases were heard by rhe bishop, accompanied by a number of priests and archons (local cilders). The written record of a decision was certified at the end of the cintry either by the bishop alone, affixing his seal, or supplcmented by the signatures of the witnesses - in their own hand or added by the scribe. All witnesses were male; in one known case a Muslim also signed. The detail of decisions recorded varied accurding to the nature of the dispute and the degree of questioning by the bishop, who might also allow expert witnesses to assess the sratements. ${ }^{31}$

In some cases, confession proved full proof of a claim; observable signs were also accepted as full proof. However, documentation was the most important cool in the litigation process. This could consist of copies of starements, wills and dowry contracts registered in the codex, büccets (deeds) issued by the kadi, or accounting books of trading partners. ${ }^{32}$ All documents hald equal weight in court. If a document was disputed or was said to have been obrained by force, a minimum of two witnesses were examined, sometimes under threat of aphorism and an oath when there was no other proof . ${ }^{31}$ Once a decision was reached and registered, the bishop would write an aphorism to deter anyone who might wish to dispute his decision in future. There is no further evidence of another form of punishment exercised by the metropolitans. However, one reference suggests that they were alwire of community punishment. In 1700, a proven adulteress was nored in the ecclesiastical record as having been 'punished by her own community with external punishment?"."

The material contained in the ecclesiastical codices provides information on a wide range of personal and family matters, as indicated by the cases registered in the codex of Sisaniou in Macedonia, dating from 1686 onwards. ${ }^{35}$ The majority are inheritancerelated. Wills were registered in the codex; heirs sought the intervention of the bishop where misunderstindings arose regarding the division of property; under-ige children's property was handed over to their guardians after the division; adopted children sought their rights in court. A significant part of the codex is also devored to financial disputes among trading partners, the earliest dating from 1688 , or to the acknowledyment and payment of debts. Only a few cases are related to civil law, for example, disputes over the boundaries of a house. The codex has a few entries on monastic properties, the refurbishing of churches, and debts owed by clergymen. Communal debts and dispunes agatinst other communicics were infereguently registered, and not before the nincteenth century. 'This was probably the result of administrative changes following the issuance of the Hatti Himayun of 5839 , a (ircek translation of which is found in the codex. ${ }^{30}$ 
Although inheritance is well represented in the code, marriage and dowry contracts are absent, and there are only four cases of divorce, due to fornication, illness of the spouse or abandonment. This strengthens the hypothesis that orher codices, perhaps thematic ones, were kept in parallel. This assumption is supported by the contents of the codex of Trikkes in Thessaly. ${ }^{37}$ Relating to a relatively small metropolitan see, this codex includes encries on various ecclesiastical and property matters, but the greater part of is is clevored to family law, especially divorce, pre-nuptial gifts, dowry contracts, inheritance disputes, the appoinement of guardians, claims of inheritance upon maturity, and wills. The same is true for the codex of $\mathrm{Kos}$ (Chios), where, ouc of is) I notary and judicial decisions, fifty-nine were divorce cases.

We can tentatively conclude that the registration of cases heard in the episcopal courts was voluntary. Litiganes applying to the ecclesiastical court received the decision of the metropolitan in a scparate sheer. If they then wished to have the decision registered in the codex, as we conclude from a 1735 entry, the registration fee was high (s aslan gurus), perhaps prohibiting the registration of all decisions. ${ }^{38}$ Indication of the need to register is stated in some entries in the codex of Sisaniou and Siatistas: 'a copy [of the decision] should be registered in the present Holy Codex, as it is the custom, and it should be sealed to have weight and power in any courc [kritirio] incernal [communall and external [Ottoman]' ${ }^{39}$ In cases of sulh (amicable settlement), the litigants agreed to provide each other with a biücet obtained from the kudi als a further guarantec. Registration in the codex was to be used as proof of the agreemcint. ${ }^{\text {it }}$

This examination of ecclesiastical justice therefore points to a legal body, inicially concerned mainly with family law, which from the late seventeenth century accjuired greater significance within Orthodox communities. Litigants who sought ecclesiastical court justice were prepared to register episcopal decisions officially in ecclesiastical codices, despite the considerable cost involved. Ottoman recognition of this role of the Church, as reflected in eighteenth-century berats, allowed Christi:un litigants to use the episcopal court, the decisions of which were binding. Those who wished co strengthen their position further could also register the decision of the non-Muslim court in the kudi court. By the late eighteenth century, the Church had succeeded in expanding its jurisdiction co civil law. ${ }^{i 1}$ This was a de facto development, resulting from the increased political role given by the Ottomans to the Patriarchate of Istanbul, which in $1766-7$ annexed the rival Patriarchates of Ochrid and Pec. ${ }^{22}$ This judicial expansion of the jurisdiction of metropolitan courts in the Aegean islands is atcested in the many calses of real escate and other civil differences judged by the metropolitan of Paronaxia (the islands of Paros and Naxos) during the entire second half of the eighteenth century. ${ }^{i .1}$ As a resule of these developments, the Orthodox Church came to operate antagennistically with the other source of justice available to Christians in the ()tcoman empire - i.c., the communal courts.

\section{COMMUNAL COURTS}

A number of theories have been proposed to help explain the existence of communat courts in rhe Gireck lands under the Otromans. These fall into two main groups: chose which maintain the uninterrupted continuation of communal insticutions firom ancient times to the present ${ }^{44}$ and those which propose the importance of Ottoman influence on the development of local community councils. ${ }^{\text {is }}$ Most of the available 
sources, dating from the mid-seventeenth century, support the second theory. A firther indication of the 'informal' development of Christian communities in Greece is the fatcr that community courts varied regionally in numbers and organization.

Communal justice was far more complex than ecclesiastical justice. In the Aegean, previous Frankish/Venetian legal practices interacted with Byzantine legislation, 'local custom" and Ottoman influence in an idiosyncratic manner unique to each island. This is a fascinating and as yet unexplored subject. In communal courts the majority of members were community elders, elected annually. Clergymen sometimes participated, but as representatives of the community rather than of the Church. Occasionally, Ottoman dignitaries such as voyvodas or dragomans were members, or appointed local elders as their representatives. As most of these officials were Christians, wc would have to examine their role in court ro determine whether they participated officially as members of the Ottoman administration or simply as negotiators to eradicate points of conflicr. "1n As in ecclesiastical courts, procedure was oral, conf ession was considered to be full proof, and oath coupled with the threat of aphorism was administered in case of a lack of evidence. Documents were copies from the communal codes, private documents signed in fronc of witnesses, or any official Ottoman documentation. Community council decisions were generally respected within the community, although community members were free to apply to other courts. Where decisions were contested, appeal could be made to the Ottoman courts or to the kapuden passa (the Ortoman chief admiral), in whose governorate the islands lay. Favourable decisions would be taken back to the communal court for acceptance and registration. As the expense of 'external litigation' was high, it was of ten agreed beforehand that the parry referring a case to the kadi would have to bear the cosrs.

Local community elders used fines to add weight to their decisions. As a further sanction, in a society where community and neighbourly assistance was important, non-compliant members could be deprived of communal procection. In a cilse from Syros in 1761, a woman named Margarita had been unco-operative and refused to comply with the advice of the castelano (clerk of the court) that she remove stones fiom the front yard of her neighbour's house. The elders decided to hand her over to the Orroman officials who were visiting the island so that she could be punished and forced to pay a fine. She was also ordered to pay indemnities to her neighbour for his losses. Finally, she would not be defended by any epitropos or proestos (communal cleders) in the ()comaln court, and would have to pay a fince of 20 gums ro the representarive of the agia (the local tax collector), regardless of the outcome of the case. ${ }^{77}$

Community council records from the Aegean islands derail a wide range of civil law cises, in particular business deals, debr and criminal punishmenc. ${ }^{18}$ They are also a parcicularly useful source for assessing local-Otcoman relacions. This is due, firstly, to the generally more idiosyncratic narure of the Otcoman presence in the islands than on the mainland. Local communities were allowed to continue pre-conquest judicial practices, with the result that a substintial number of extant sources, including adjudication and notarial documents, are preserved. Secondly, since representatives of Otcoman justicc were not always readily available on each island, and on account of the 'privileges' granted to these communities, we can trace the interaction between different sources of justice, communal and Otcoman. Most of the istands came under ()toman rule in the fifteenth century; in I 52.2 Rhodes was captured from the Knights of Sr John, and in 1537 Syros, los, Paros, Antiparos, Skyros and North Sporades were 


\section{- Jastice in Oobriman Gireces -}

added to the province of the kapudan pasa. Ortoman sovereignty was established on Chios in 1566 and, in stages, on Naxos by the $15805 .{ }^{\text {i" }}$ "Whether these islands were autonomous areas or were integrated into the Otcoman system (and, if so, to what degree) is a subject of debace. ${ }^{50}$

In the abdnarness given to the population of Chios in 1567 and to Naxos, Paros, Andros, Mylos, Syros and Santorini in 1580, the balance between Otcomann and local justices was carrefilly delineated. For example, new judicial cases could be heard by sancak be yis, kadis or naibs, but they were not allowed to judge cases which had already been heard in Christian courts and had to accept previously held documentation. If someone appealed against a previous decision, the kadi could not interfere, but had to leave the islanders to solve the dispute among themselves. If they chose to resort to the arbitration of a third party, the kadi would simply verify the settlement. Wills would be respected, and could not be interfered with by local dignicaries. No one could force Christian women to marry against the (canon) law. If a person had a dispute, he or she would nor be prevented from bringing the case to the Ortoman court; neither the sancak boyi nor the kadi could prevent anyone from petitioning and complaining to the Porte. ${ }^{52}$

In similar fashion to the berats of ecclesiastical auchorities, athdnames portray the fiamework of judicial freedom granced to Aegean islanders. The undisputed authoricy of local arbitration and the use of legal documentation suggest that the subscquent pursuit of justice in the Ottoman legal system was much more complicated than appears when using only kadi court records. The right to apply to any court or arbitration body is established again in the imperial orders and was exercised by (.hristian subjects even in 'highly self-governed' communities. The right was fiequently exercised by islanders, despite the physical effort and high costs involved in having a case heard before the kadi, especially for those who had to travcl to find the representative of 'imperial justice'.

\section{INTERACTION OF ECCLESIASTICAL AND COMMUNAL JUSTICE WITH OTTOMAN JUSTICE}

It is now clear that, contrary to the impression given when using only Otcoman records, nnn-Musli ms off en used horh rheir own and Orcoman coures on matters which. strictly speaking, should not have involved the Ottoman authoritics. 'This occurred in cases either where their own systems of justice did nor produce the desired resuls (as of ten in divorce cases) or where the extra authority of the kadi's court could ensure that a decision was carried out. Kadis were appointed to large and important islands such as Chios, Rhodes, Mycilene, Paros, Andros and Samos. Foreign cravellers visiting the islands atcested to the fact that sometimes the kadi was almost the only Otcoman presence there. The traveller Tournefort reported that smaller islands relied on travelling kndis, who adhered to local custom and accepted the services of community slders. Frequent corsair attacks, or Veneci a n-Turkish wars in the seventeenth century, of ten resulced in the evacuation of the kadi for saftecy reasons. ${ }^{53}$ The presence of corsairs in the region had further ramifications for the adminiserarion of justice. Tournefort notes that the Knights of Malta would occasionally answer the complaints of Catholic islanders against Grecks, and would administer fines or strokes as punishmenc. 
other source of Otcoman justice on the islands was the kapudan paşa, as provincial governor and recipient of most taxes..$^{55}$ Cases could be heard on appeal in his council or on his annual tour of the islands. The rote of the dragoman (the admiral's Greekspeaking translator), who was instrumental in the preparation and execution of cases, increased towards the end of the eighteenth century. ${ }^{56}$

Since the Church was reluctant to dissolve marriages, spouses applying for a divorce would be advised to reconsider, and the bishop mighe intervene personally in order to eliminate some of the sources of grievance and prevent separation. Dissatisfaction with this procedure could lead to an appeal to the kadis court. For example, in 1704 a young woman named Eirene presented her case in front of the metropolitan and the clergymen, and requested separation and divorce from her husband Triantafyllos, claiming that he was cruel and beat her daily. On being summoned to court, her husband was reprimanded, but to no avail. Eirene then 'decided to berray her belief in the church, and although she would be punished by God, she went to an external courr [i.e., the kadi courr] and she was separared from his [her husband's] ryrannical hand'. 'The bishop subsequently accepred the kadi's ruling and a divorce sertlement in which Triantafyllos promised to recurn to Eirene her dowry and half of the pre-nuprial gift $5 .{ }^{57}$ This is an excellent example of how ecclesiastical and Otroman courts could be used to the same end by a non-Muslim. After her inirial failure to obrain a divorce from the bishop, Eirene applied successfully to the kadi, but she still needed to have her divorce recognized by the ecclesiastical court in order to gain a recognized canonical divorce, which would permit her to remarry without difficulty.

In a edispute registered on Syros in 1763, Linardos Halavazis applied to the kadi's coure in an artempe to force his father-in-law to recurn propercy previously given as dowry and which the later had repossessed while the litigant was absent in Istanbul. ${ }^{5 *}$ It is not clear wherher linardos had tried communal justice before raking his cause to the Otromans, but the executive authority behind the kadi's decision must have been the reason for his application. However, in the islands the kadi's decision could be implemented only by the local, communal administration. In this case, it did so by banning I.inardos's no nzcompliant father-in-law from access to the disputed property under threat of a fine payable to the local Ottoman dignitary, in the certainty that, if necessary, this would be collected.

Somerimes litigants tried their luck in two different kadi courss before reaching an agreement. In 1682, in the disputed case of a field left by will to a monastery, the heirs claimed it from the prior of the monastery in the presence of the kadiand won. The prior then rook the case to anorher kadi, who judged in his favour. The rwo parties subsequently reached agreement by negoriation between themselves, as the costs of raking the same case to different forums was high."

On the orher hand, fear of being taken to the kadi somerimes led to injustice. In 1685 a woman called Frosyne appealed to the communal court against a creditor of her deceased husband who, she claimed, had forced her ro sign a pledge in the kadi courr. The local court, raking into consideration that a judicial acr was made under duress, promprly recrified ir. Equally, both local Otroman officials, such as voyvodas, and community elders were themselves reprimanded if they violated local custom and/ or Otroman law. (1)

A variety of crimes might be referred to the Ottoman court if they could nor be dealt with satisfactorily by communal courts and their punishments. Petry theft and 
damage to property and persons werc dealt wich internally by the communities, who tended to be lenient in order to avoid involving the imperial auchoricies. However, habicual offenders were turned over to Otcoman justice. "1 Slander was punishable in an Ottoman court if accusations of guilt concinued to be made after an accused had been cleared of wrongdoing by the kadi. Incidents of bodily harm incurred indemnities, following the prescriptions of Otcoman law. In cases of homicide and rape, kidnapping, prostitution and other sexual crimes, Otroman officials or their representatives had ulcimace auchority over judgements.

Finally, communal documents can shed light on the sulh procedure observed in the kadi court, andl particularly on use of written evidence in the Muslim court, where tradicionally words and witnesses played a more significant role. In one case, where the kad $i$ could not decide after hearing the two parties, he summoned the elders of the communicy and asked chem to investigate the 'lecters of the two sides presented to him, and to tell him whatever they knew about the case, so that he would decide'. ${ }^{1,2}$ While Ottoman documents such as the bisccet were accepted in communal courts, locals occasionally had problems reading Otcoman, and decisions based on them could be conditional. ${ }^{\text {(3) }}$ Many Turkish loanwords, especially judicial and caxation terms, found their way into the Greek communal and ecclesiastical records. Somecimes even full Ottoman phrases were included to avoid any misunderstandings and the subsecpuent concesting of the decision. ${ }^{64}$

\section{INTERIM CONCLUSIONS}

The claim that ecclesiastical and communal courts were no more than legend is clearly disproved by the above discussion of ecclesiastical and communal records. However, the existence of these records raises many other questions. In terms of judicial autonomy it appears that, on the whole, until che eighteenth century, ccclesiastical jurisdiction followed the rights granted by the sultans in the appointment berats of patriarchs and mecropolitans, and that it covered primarily family law. Even the expansion of Church jurisdiction to include arbitration cases was inicially only granted $d c^{\prime}$ jure for family-related issues. e facto, as we can deduce from parriarchal interventions in civil cascs, Christians applied civil dispuces to the judgement of clergymen, albeic informally. This ambiguicy abouc rights and responsibilities allowed the parriarchate to take the lead and establish an undisputed auchority from the mid-eighteench century, not only in the traditionally accepted area of fumily law. but also in civil law. It is not coincidental that Byzantine legal manuals such as the Hexabiblos were published and widely circulated around the same time to 'educate' clergymen on issues of civil law. ${ }^{15}$ The political support enjoyed by the patriarchate after the annexation of rival patriarchates and the active involvement of Phanariots in church affairs facilitared the id hoc expansion of ecclesiastical jurisdiccion. No research has been done on whether the Otcomans were aware of and fully supported such developments. However, we do know that local Chriscian communities were not at ease with the expansion of the judicial authority of the Church to civil law, since this was considered a communal responsibilicy.

Regardless of whether the sultans endorsed or ignored the decisions of the patriarch, in the seventeenth century provincial administrative and taxation retorms began to creace more coherent Christian communicies. They also allowed local agents, clergy 
or laymen to act as mediators between the centre and the periphery and as translators of the communal voice through the iltizam system. To some extent, Aegean island communities had already atrained this status in the sixteenth century as a result of the idiosyncratic character of Ottoman conquest and presence. Local community councils, although diffiering in structure according to local custom, judged and registered decisions of law on obligation, succession law, commercial law, property law and even torts against persons. Documentation, being important in the litigation process both inside the communities and in Ottoman courts, produced admirable volumes of notarial and community records. Scholars have identified elements of Byzantine and Frankish/Venerian law, which show that the legal structure and notarial tradition inherited from previous rulers was allowed to continue under the Ottomans. However, a large part of what is termed 'local custom' still awaits proper attention from experts in Ottoman law. Even in such a highly independent legal system, there was clearly an unimpaired legal choice to transf er cases to Ottoman courts; the Ottoman administration and its legal system were urilized in ingenious ways ar every stage of litigation. In orher words, the level of judicial autonomy local communities enjoyed neither hindered individual freedom of legal choice nor undermined Otroman law as the law of the land. However, the supremacy of Otroman law did not necessarily compromise earned legal privileges. Cases were reviewed and decisions of Otroman dignitaries were cancelled if they were in obvious conflict with local custom. ${ }^{66}$

A second ser of unanswered questions is related to the reasons why ecclesiastical and communal court records were codified mostly in the seventeenth century. Christians paid handsomely ro have their decisions, witnesses, our-of-court sertlements and contracts registered in Christian codices. According to the entries, this was to safeguard the owners of documents from fut ure claims in the Christian or Ottoman courts, or in order to be used as part of their litigation strategy in 'external' and 'internal' justice. We can presume that this was a result of the general legal awareness that Otroman subjects exhibited from this period onwards. The judicial system became more organized, the kadi expanded his jurisdiction even to penal law, and communities and individuals explored the right of appeal to the Porte and registered their complaints in sikayet defterleri (registers of complaints). ${ }^{67}$ Christians and Muslims seemed to be more legally educated. Many private documents atrest to the writing up of contracts in the presence of bishops without a subsequent registration in episcopal codes. However, the question remains as to why certain communiries did nor codify Christian courr decisions or did s• very late (around the turn of the ninereenth century). Until detailed regional studies emerge, we can only guess that the legal 'autonomy' of Christians was determined by the degree of Otroman 'stare' manif estation. Thus, in certain Greek lands, such as the mainland, where community organization did not or could nor develop beyond its taxation duries, the metropolitan codices were sufficient to supplement the kadi sicils. Other factors to take into account are the influence of existing legal tradition and practices and literacy levels in different areas of the Ortoman empire.

The Christian court records further our knowledge of the function of the kadi and the administration of Ottoman justice. Documents written in Greek were presented to kadis nor only to establish the identity of the parties and witnesses involved but also as judicially legirimate sources of information. ${ }^{\text {hy }}$ These could include written registration of a previous oral agreement. (") Christian ecclesiastical and communal court records complement the silence of the kadi records regarding the identity of arbitrators 


\section{- Justice in Ottoman Greece -}

and their function where the names of the witnesses and the terms of the agreement are clearly registered. The system of arbitration was highly developed, with threars of excommunication and fines employed so guarantee acceptance of the decision.

Finally, the Christian archives provide a glimpse of local networks ready to offier legal and other assistance to all Ortoman subjects, regardless of faich or legal status. For instance, it has always been assumed that kadis received a certain amount of local help, given that they changed posts frequenrly. Local records provide evidence of local community leaders (noted under terms such as ayan-t nasara) assisting travelling kadis on their visits to remote islands and co-operating with local Ottoman dignitaries to uphold morality and to demand the expulsion of undesirable offenders. Similarly, Ottoman dignitaries provided statements to facilitate claims registered in notarial codes. However, there is a lot yet to be done to identify whether social status was a determining factor in achieving legal pluralism. We should note, however, that utiliz ing any 'legal tool' to attain justice was not a practice exclusive to Christians. Muslims were also aware of the power of certain Christian legal tools and could use these in their pursuit of justice. When in 1784, Sah Sultan sent her tax collector Yusuf Ağa to Andros to collect her dues, he asked for a new evaluation of taxation and requested an aphorism fiom the local bishop to ensure that the Christian estimators did their job fairly. ${ }^{70}$ Examples like this indicate the complex legal environment shared by Muslims and Christians in Ottoman society.

\section{NOTES}

* A longer version of this essay, containing additional references and comments, was originally published in Andreans Christmann and Robert Gleave (eds), Studies in Stamic law: a Festschrifis Jor Colin Imber (Oxford, 2007): 165-210 Uournal of Semizic Studies, supplement 23]. 1 am grateful to the editors and to Oxford Universicy Press for permission to publish this version.

I Braude and Lewis i982: 1 .

2 According to the millet system theory, the head of the Orthodox, Armenians and Jewish millet wals personally responsible for the aff airs of the comrnunicy vis-à-vis the lorte. They atred as the administrative officer responsible to the state for their community, and to their commonicy for the stace, miantianing the fiscal and juridical atutonomy of each recognized community. Thus, through this system the Otcoman deale with their non-Muslims as members of al community, not as individuals.

3 Karpalt i982: 142 .

it-Q:att:u1 1999: 431; Masters 200r: 6r.

Jennings 1973: 27I; of. Farroghi 1987a: 1 54, 209-10.

Shunuclevit: 1984; P'antizopoulos 1984: 103-7; Hacker 1994: 183-4.

[Fatt:al 1958; al-Q:atcan 1999; lnalcık 1982: II, 437.

Shmuclevice 1984: 48-9; Goodblate 1952: ir 8-29.

Gradevil 2004:il; cf. Ergene 2003: 18I-4.

10 Shrnuclevice 1984: 66-7, 69; Cohen 1984: 110-39.

I Hacker 1994: 18 i

I 2 al-Q:atciul I 999: 432.

I Many have been published in Greek, but a great number are still in manuscripe form. Fior a decailed bibliography, see Arnioutoglou, www.geocities.ws/ekeied/. Cf. Kcrmcli 2007: 167, n. I 5 , for al parrial lise.

14 Cikines 1966: 49.

Is Zacharriadou 1996.

I6 Cf. Konortis 1998. 
17 Paparrygopoulos i858: 219-20; Paparrygopoulos 1896: 5/2, II 5; Vaccilopoulos: 1976: II, 137.

18 Cf. Vartin and V cinstcin 2004: 9-10.

1) Oikonomides 1968: 187-9.

20 l.owry 2002: 38-4I, for an aleernative reading of this document; cf. Kermeli 2007: 172, II. 23.

21 Kermeli 2007: 173-4, for two calses of arbitration between laymen (one of them involving a T'urkish 'lord' and che kadis court) in che I 570 s.

22 Mihaclaris 1 997: 269-335.

23 Ziachariadou 1996: 94-5. This is in accordance with the lslamic prescription wherein collectiv iry is nor legally recognized.

24 Zachariadou 1996: 158.

25 Zachariadon 1996: 174.

26 St:ivrinides $1972-85$ : II, 3 I 2-I4.

27 lbid.: II, 248, 250, 393.

28 Hid.: II, 3 I 3.

29 lbid.: Il, 313-Is; Kermeli 2007: 175-6.

30 Kermeli 2008.

3 I Kermeli 2007: 192-3, o n the law books used by the ()rthodox Church in the seventecenth and eightecenth centuries.

32 Panticopoulos I984: I I 7, 67, 80-I, II 3-Is respecrively.

33 Giannoulcs 1980: 50; Pantazopoulos 1984: 20.

34 P'ant:izopoulos 1984:69.

35 Pantazopoulos and Papalstathi r 974: passim.

36 Cf. Kermcli 2007: $178 \mathrm{ff}$., for detailed references to the codices discussed in this section.

37 Giamoules s980.

38 Panka\%opoulos and Papastathi 1974: doc.99, 18-19.

39 E.g., ibid.: 103, doc. 79, dared I7I9.

40 lbid.: 89, doc: 7 I, dated I7 Is.

4I P:antazopoulos 1984: 44; Gkines 1960: 237.

42 P'intatcopoulos 1984:44.

43 l.ykouris 1954:219.

44 Papirrrygopoulos i858: 219-20; Vacalopoulos 1976: II

45 Urquhare : 836: 11, 37, 43: Argyropoulos 1859: 11, 26, 36-7.

46. l'ourcoglou and Paparreg:-Artemiade 2002: 1 4-19.

47 Silaras $1997: 162$.

48 C. Kermcli 2007: 188-9.

49 Slor 1982

so Koukou 1989: I, 47-52; Vicialopoulos 1976: 1, 34 2-6; Vitrin 2004: 72-6.

s1 There is extensive discussion as to whecher al)dnames resemble 'capitulations' or were appointing clocumenrs (berrets). Unformnately, the Otroman originals have nor yee been found. However, the Greek translation of the i 580 privilege charerer given to the Cyclades islands mentioned that leronymos Somaripass, Bartholomaios Kampy and Michael l'angalos had peritioned the lore on behalf of the islanders and were granted a bernt similar to the one given to Chios. The confusion in terminology and the adaptation of the cerm aldrume, which denoces a covenant, srenss from the practice that alydnumes, like all jocuments conferring a privilege, were drawn up in the form of a berat. See inaleak 1971.

s2 Slor 1982: 98-100; Kermcli 2007: 184-s. For the Greck translation of the aldonnme of Chios, sece Argenti 1941: I : 3-17, 208-20.

53 Tournefort 2005: 2 18. If corsairs approached, the kadi of Syros took refuge in a monastery; if rhe kndi wass abeunceed, Syres islinders had to pay his ransom.

S4 lbid.: I45.

s5 Cf. Kerneli 2007: 187, n. ir 
56 Sfyroeras I965: 3-192.

57 Giannoules 1980: 54-5; Kermeli 2007: 190.

58 Siatras I 947: $52-3$

59 Kermeli 2007: 201

6o Tourtoglou and Paparrega-Arcemiade 2002: 31, 51-2.

Gi Koukou I989: 284-6.

62 Sifaniou-Karapar efal. в y90: 369-70.

63 T'ourcoglou 1980-8 I: 48.

64 Tourroglou and PatparregalArtemiade 2002: 32-3.

65 Kermcli 2007: t92.

66 I'the power of local custom is evident in the registration of pledging and sale of ehildren in the Orcoman coure of Crete, which was aceepeed by the kndi despite being against sharia law; cf. Kermcli 2006.

67 Gerber I 994 .

68 For the discussion on the power of documents in the sicils, see Johansen s997; Peirce 2003; Agmon 2003; Messick 1993.

69 Kermcli 2007: 208-9.

70 Michaclaris 1997: 427. 